MARTA DORENDA

Instytut Politologii UMK

\title{
Pozamerytoryczne czynniki w kampanii prezydenckiej we Francji w 2007 roku
}

Domimo faktu, iż w kampanii wyborczej przed wyborami prezydenckimi we Francji brało udział dwunastu oficjalnie zgłoszonych kandydatów, od jej zarania oczywiste było, że de facto o fotel głowy państwa mogło ubiegać się tylko dwoje z nich - Ségolène Royal i Nicolas Sarkozy. Dlatego też poniższą analizę oprę na kampanii prowadzonej właśnie przez te osoby - założenie to jest tym bardziej uzasadnione, iż działania obu pretendentów skierowane były bezpośrednio przeciwko adwersarzowi, z pominięciem innych, mniej znaczących kandydatów, co determinowało przebieg kampanii i nadawało jej kształt. Należy podkreślić, iż kształt ten, podobnie jak w przypadku innych demokracji zachodnich, podlega zasadom wszechobecnego marketingu politycznego. Działania i zachowania kandydatów na istotne stanowiska w państwie są w najdrobniejszych szczegółach dyktowane przez spin doctors, a merytoryczne treści, jakie mają (lub powinni mieć) do zaoferowania wyborcom politycy coraz bardziej tracą na wartości na rzecz umiejętnego doboru koloru stroju lub opublikowania właściwej fotografii we właściwym magazynie. Działalność specjalistów od kreowania wizerunku może jednak przybierać mniej powierzchowne, a bardziej wysublimowane formy, polegające na wykorzystaniu atutów oraz retuszowaniu niedoskonałości kandydata. W poniższej pracy przedstawię te właśnie pozamerytoryczne czynniki kształtujące francuską scenę polityczną przed wyborami prezydenckimi, aby ukazać ich rzeczywiste znaczenie w kampanii wyborczej oraz 
odpowiedzieć na pytanie, w jakim stopniu - w porównaniu do konkretnych postulatów Royal i Sarkozy'ego - przyczyniły się do jej rozstrzygnięcia na korzyść jednego z kandydatów.

\section{Kim są Ségolène Royal i Nicolas Sarkozy?}

„We Francji, zamaskowanej monarchii, w której prezydent dysponuje władzą i wpływami niezrównanymi z nikim w Europie, jego osobowość, charakter, przyzwyczajenia, mentalność, także gust, urojenia i fobie, nie tylko wizje i poglądy - odciskają się na historii. Prezydenci kształtują krajobraz"1. $\mathrm{W}$ pozornie liberalnym, przywiązanym do oświeceniowego nurtu poszanowania wolności jednostki i podążającym za procesami globalnymi, a w istocie głęboko konserwatywnym i przywiązanym do tradycji „wielkiej Francji”, kraju, głowa państwa musi legitymować się właściwym pochodzeniem. Jakie zaplecze mieli więc do zaoferowania kandydaci w minionych wyborach?

Ségolène Royal, córka żołnierza armii francuskiej, do końca opowiadającego się za generałem de Gaulle i zachowaniem imperium kolonialnego, utrzymującego w wielodzietnej rodzinie żelazną dyscyplinę, patriarchalną hierarchię oraz nienaruszalne katolickie zasady, opowiedziała się przeciw domowym tradycjom, wstępując do Partii Socjalistycznej i w swojej działalności politycznej walcząc o realizację postulatów dokładnie przeciwnych do tych, w atmosferze których ją wychowywano. Nicolas Sarkozy natomiast jest synem Żydówki greckiego pochodzenia oraz emigranta z komunistycznych Węgier, który opuścił żonę cztery lata po narodzinach potomka. Mimo trudnej sytuacji finansowej, dzięki wysiłkom matki, obecny prezydent skończył prestiżowe studia i wbrew przewidywaniom ojca, mówiącego, że Sarkozy „z takim nazwiskiem do niczego nie dojdzie” ${ }^{2}$, w 28. roku życia został merem ekskluzywnej podparyskiej dzielnicy Neuilly-sur-Seine, by kontynuować karierę polityczną u boku Eduarda Balladura i Jacquesa Chiraca.

Polityczne konsekwencje pierwszych decyzji każdego z kandydatów stanowią swoisty paradoks - Royal miała szansę kontynuować wyniesione z domu tradycje „starej Francji”, wciąż hołubione i pielęgnowane z sentymentem przez obywateli tego kraju. Mogła odwołać się do czasów świetności, kolonialnego imperium, roli Francji jako decydującego gracza w polityce europejskiej. Wstąpienie w szeregi socjalistów, zajmujących się głównie „prostym ludem”, którym w opinii znacznej części Francuzów jest elektorat kandydatki, zostałoby zapewne uznane za młodzieńczy wybryk i wybaczone.

M. Ostrowski, Gazela szybsza od słoni, „Polityka”, nr 9, 2007, s. 53.

C. Nay, Un pouvoir nommé désir, Paryż 2007, s. 114.

C. Askolovitch, Qui connaît Madame Royal?, Paryż 2007, s. 36. 
Ségolène postanowiła jednak kontynuować działania na rzecz uboższej warstwy społeczeństwa, zrównania statusu płci, polepszenia losu imigrantów oraz ochrony środowiska naturalnego. Postawiła na cele niewątpliwie szczytne, lecz w niewielkim stopniu interesujące tych, których głosy najbardziej się liczyły - klasy średniej i wyższej, zamożniejszych, rdzennych obywateli Francji. Ich kandydatem stał się ktoś, kto niefortunne pochodzenie zatarł zwielokrotnionym entuzjazmem w działaniach na rzecz przywrócenia nadwątlonej potęgi kraju; ktoś, kto „zdecydował się być Francuzem w stu dziesięciu procentach, by pokazać jak bardzo jest zakotwiczony w nowej społeczności" $i$ kto jednym ze swoich czołowych haseł uczynił rupture - zerwanie $z$ dotychczasowym porządkiem ${ }^{5}$. Nastąpiło zaskakujące odwrócenie preferencji wyborczych - kredytem zaufania została obdarzona nie kandydatka z rodziny o gaullistowskich tradycjach, lecz syn ubogich imigrantów, symbolizujących we Francji wszystko, co złe - kryzys ekonomiczny, bezrobocie oraz upadek obyczajów.

\section{Jak przekonać wyborców? - techniki kampanii prezydenckiej}

Tak jak w przypadku każdych wyborów prezydenckich we Francji, kampania rozpoczęła się wyłonieniem kandydatów przez partie polityczne. Już ten etap stanowił dla Ségolène Royal dużą trudność. Mimo że została wyznaczona na mocy głosowania, ze strony Partii Socjalistycznej brakowało nawet oficjalnych, grzecznościowych deklaracji o działaniach na rzecz kandydatki. Zarzucano jej bycie „produktem medialnym”, mówiono o braku wizji, konkretnych propozycji. Sarkozy natomiast, mimo formalnego poparcia jedynie Unii na Rzecz Ruchu Ludowego, cieszył się przychylnością większości prawicowych polityków, świadomych faktu, iż gra toczy się między dwiema stronami sceny politycznej i nikt poza Sarkozym nie jest w stanie skutecznie działać na rzecz konserwatystów.

W kampaniach wyborczych we współczesnych demokracjach zachodnich trudno uciec od retoryki „towaru politycznego". Teoretyczny aspekt owego „towaru”, „produktu” to działania stricte marketingowe, natomiast na jego praktyczny równoważnik składają się dążenia, aspiracje, chęć objęcia władzy - czy to w celu realizacji dążeń określonych grup, czy też w wymiarze autotelicznym ${ }^{7}$. Strategie marketingowe w kampanii wyborczej wpisywa-

\footnotetext{
M. C. Royen, Sans Le Pen...je suis mort, „Le Vif”, nr 72, 2007, s. 4.

K. Niklewicz, Co Nicolas Sarkozy proponuje Francji, ,Gazeta Wyborcza”, nr 116, 2006, s. 8

J. Muszyński, Teoria marketingu politycznego, Warszawa 2004, s. 165.

Tamże.
} 
ły się w ów ekonomiczny paradygmat. Dokładnie odzwierciedlały one programy kandydatów - Sarkozy uprawiający „wielką politykę” prowadził kampanię z dystansu i kierował ją do wyższych warstw społeczeństwa. Royal, zgodnie z socjalistycznymi ideałami zwracająca się do „nizin”, ale i do klasy średniej, w obliczu problemów ekonomicznych stanowiącej znaczną grupę wyborców, postawiła na bezpośredni kontakt. Posługiwała się prostymi, sugestywnymi hasłami, unikając wykluczania i komunikatów negatywnych. Promowała wartości bliskie każdemu, niezależnie od statusu społecznego odpowiedzialności, solidarności, rozwoju ${ }^{8}$. Każdy z kandydatów wykorzystał w kampanii zestaw podstawowych technik zdobywania poparcia, zwany promotion mix, na który składa się reklama, marketing bezpośredni, promocja sprzedaży, public relations oraz sprzedaż osobista9. Podporządkowanie się regułom rynku politycznego nie oznaczało jednak bezrefleksyjnego stosowania się do zaleceń specjalistów od kreowania wizerunku. Aby kandydaci nie byli $\mathrm{w}$ swych rolach postrzegani jako sztuczni więźniowie reklamy, należało spersonalizować asortyment środków, do których się odwoływali, dostosować je do oferty wyborczej i obrazu kandydata w oczach odbiorców. Tak też Royal oparła swoją strategię na niezliczonych spotkaniach, stylizowanych na wizyty bliskiej osoby, rozumiejącej przyziemne problemy i sprzeciwiającej się bieżącej sytuacji. Dowodziły tego także liczne dyskusje, które prowadziła z wyborcami, niezależnie od ich statusu. Nie miała na swoim koncie obraźliwych wypowiedzi pod adresem żadnej grupy społecznej, nie musiała więc obawiać się wystąpienia $\mathrm{w}$ jakiejkolwiek dzielnicy lub regionie, w przeciwieństwie do Sarkozy'ego, który był zmuszony unikać konfrontacji z tymi, których wcześniej obraził lub publicznie uznał za niebędących adresatami jego kampanii - nazwanie młodzieży z rodzin imigranckich „hołotą” i zapowiedź, że ,jeśli będzie trzeba, wyczyści wszystko Kärcherem” lub że „skuje mordę" Azouzowi Begagowi, politykowi pochodzącego z Maghrebu ${ }^{10}$ oraz liczne deklaracje poparcia dla Izraela, spowodowały, iż nie zaryzykował on żadnego spotkania z mniejszością muzułmańską, stanowiącą ponad $10 \%$ elektoratu, przez co uzyskał niecały $1 \%$ głosów tych wyborców, natomiast jego przeciwniczka przekonała $64 \%$ osób wyznania islamskiego ${ }^{11}$. Spotkania wyborcze Royal często odbywały się w plenerze, dbano o niezobowiązującą atmosferę i zachowanie konwencji pikniku dostępnego dla wszystkich. Sztab

D. Revault, Royal fait bonne figure, ses amis montrent les dents, „Libération”, nr 17, 2007, s. 8.

M. Janik-Wiszniowska, Promocja i reklama polityczna, w: Marketing polityczny w teorii i praktyce, A. W. Jabłoński, L. Sobkowiak (red.), Wrocław 2002, s. 172.

10 Dostępne: http://politique.fluctuat.net/nicolas-sarkozy/commentaires.html [20.01.2008].

11 Sondaż CSA-CISCO, dostępne: http://www.csa-tmo.fr/dataset/sondages-presidentielle2007.asp [22.04.2007]. 
Sarkozy'ego natomiast skrupulatnie dobierał miejsca, w których kandydat spotykał się z elektoratem, podobnie jak selekcji podlegali sami uczestnicy spotkań. Kontrowersje, jakie wzbudzał prawicowy kandydat, mogły prowokować do głośnych akcji skierowanych przeciwko niemu, a relacjonowane na żywo wydarzenia przerodziłyby się w skandal. Wielkie hale, ozdobione wyszukanymi dekoracjami w stonowanych kolorach oraz wyposażone w odpowiednie oświetlenie, ale także bankiety oraz kameralne przyjęcia ze starannie wybranymi gośćmi - w takim otoczeniu przekonywał do swoich atutów Sarkozy. Używał przy tym haseł kojarzących się z dynamiką, działaniem, odwagą. W przeciwieństwie do Royal, która proponowała i sugerowała swoje rozwiązania, formułował on zdania $\mathrm{w}$ taki sposób, by przedstawić własne plany jako nieposiadające rozsądnej alternatywy i bezpośrednio prowadzące do poprawy sytuacji w państwie.

Ségolène Royal, zgodnie z koncepcją dotarcia do jak najszerszego grona odbiorców, często posługiwała się w swojej kampanii Internetem. Założyła ona blog polityczny ${ }^{12}$, na którym przeplatała notatki stylizowane na osobiste $\mathrm{z}$ przemyśleniami dotyczącym kampanii, innych kandydatów oraz otwartymi apelami do potencjalnych wyborców. Posłużyła się także popularnym serwisem Facebook, oferującym możliwość zaprezentowania w sieci osób, z którymi łączą nas różnego rodzaju powiązania. Upubliczniła zdjęcie, na którym jest roześmiana i otoczona tłumem ludzi, a do jej profilu ${ }^{13}$ może dopisać się każdy zalogowany internauta. Wykorzystana została także ogromna popularność serwisów youtube.com oraz kawego.fr (francuskojęzyczny odpowiednik youtube.com), na którym umieszczono krótkie filmy dokumentujące wystąpienia oraz wyrazy poparcia dla kandydatki. Royal propagowała również głosowanie za pośrednictwem Internetu, możliwe we francuskim prawie wyborczym.

Nicolas Sarkozy początkowo uznał Internet za „narzędzie poza prawem" $\mathrm{i}$ korzystał $\mathrm{z}$ niego jedynie $\mathrm{w}$ takim stopniu, $\mathrm{w}$ jakim było to konieczne w epoce powszechnej informatyzacji. Nie jest to zresztą zaskakujące, gdyż jego działania nie były skierowane w stronę „mas”, dla których źródłem informacji oraz miejscem wymiany poglądów są strony internetowe. Wkrótce jednak, za namową członków sztabu wyborczego, podkreślających fakt, iż z sieci globalnej korzystają nie tylko nastolatki, ale także np. przedsiębiorcy i inne grupy społeczne, do których Sarkozy adresował swe postulaty, zwrócił się ku temu medium, obsługę kampanii w Internecie pozostawiając swoim podwładnym i przeznaczając na ten cel 80000 euro. Stając ostatecznie na

Dostępne: http://www.segoleneroyal2007.net [20.12.2007].

Dostępne: http://www.facebook.com/people/Sgolne_Royal/716033620 [20.12.2007]. 
stanowisku, iż „żaden polityczny aktor poruszający się w obrębie otwartości medialnej społeczeństwa informacyjnego nie może rezygnować z nowoczesnych strategii komunikacyjnych w Internecie" ${ }^{14}$, fundusze przeznaczono na stworzenie strony internetowej kandydata, stanowiącej przedłużenie audycji wyborczych w mediach - na stronie sarkozy.fr pod nazwą „NS TV” umieszczono m.in. krótkie filmy prezentujące przyszłego prezydenta w różnych sytuacjach, podzielonych na kategorie - w ten sposób widz mógł wybrać „kanały” tematyczne, takie jak „życie rodzinne” czy „podróże”"15. Jakość wykonania strony Sarkozy'ego została oceniona dużo wyżej niż witryna kontrkandydatki - spokojne, zharmonizowane kolory, ujednolicony szablon, przejrzystość, aż wreszcie zawartość prezentowały się lepiej niż krzykliwe barwy, wielość czcionek oraz elementów graficznych, chaotyczne hiperłącza i nie do końca spójna treść strony Royal. Fundusze wyasygnowane przez kandydata UMP posłużyły także na przeprowadzenie internetowej akcji rozpowszechniania poparcia, polegającej na przekazywaniu przez osoby prywatne (kontaktujące się przez nieistniejący już serwis lessuporteusdesarkozy.com) pozytywnych komunikatów o Sarkozym wszelkimi metodami oferowanymi przez Internet - poprzez blogi, komunikatory, nieoficjalne strony internetowe oraz dostęp do portali tematycznych ${ }^{16}$.

Tradycyjnym i znanym każdemu środkiem oddziaływania w kampanii wyborczej są plakaty. Ich użycie przez zwolenników socjalistki przed wyborami w 2007 r. odznaczało się dwoma ciekawymi cechami. Pierwszą z nich była ilość - niemal każda dostępna (niekoniecznie legalnie) powierzchnia została oblepiona afiszami - nie tylko oficjalnymi, o ujednoliconym wzorze, lecz także wykonywanymi mniej lub bardziej profesjonalnymi metodami arkuszami głoszącymi poparcie dla Royal oraz niechęć do jej rywala. Odwrotna sytuacja nie miała miejsca, gdyż elektorat kandydatki stanowili w dużej części młodzi ludzie, a wśród nich uczniowie i studenci - po pierwsze, bardziej niż stateczni, ustabilizowani i poważni wyborcy Sarkozy'ego skłonni do angażowania się w spontaniczne akcje poparcia, po drugie - dysponujący dostępem do wielu nieformalnych kanałów przepływu informacji, po trzecie posiadający umiejętności oraz zaplecze techniczne do domowej produkcji prostych w formie, lecz bardzo wyrazistych w przekazie afiszy, a wreszcie niepozbawieni brawury, pozwalającej np. oblepić nimi wszystkie szyby uczelnianego budynku lub przystanki tramwajowe w całym mieście. Kolejną,

${ }^{14}$ S. Gawroński, Marketing polityczny online, w: Marketing polityczny. Szansa czy zagrożenie dla wspótczesnej demokracji, P. Pawełczyk (red.), Poznań 2007, s. 221.

15 Dostępne: http://www.sarkozy.fr/video/index.php [20.01.2008].

16 Dostępne: http://www.zdnet.fr/actualites/internet/0,39020774,39366259,00.htm?xtor=AL$200[20.01 .2008]$. 
dużo istotniejszą kwestią związaną z plakatami, która wzbudziła (później odrzucone) wątpliwości Centralnej Komisji Wyborczej, była zastosowana przez sztab Royal kolorystyka. Prawo wyborcze we Francji zabrania stosowania barw narodowych (jeśli występują łącznie) dla celów kampanii. Afisze kandydatki zostały wydrukowane $\mathrm{w}$ dwóch wersjach - biało-czerwonej i białoniebieskiej, co zapewniało im zgodność z przepisami. Były one jednak nalepiane na przemian obok siebie, co w oczywisty sposób tworzyło wzór flagi narodowej. Oficjalne plakaty Royal także nawiązywały do sposobu prowadzenia kampanii. Zaprojektowano je w konwencji fotografii gwiazd filmowych z lat 60. Twarz zajmuje całą powierzchnię afisza, co, wraz z nieformalnym stylem wykonania, sprawia wrażenie familiarności i bliskości z odbiorcą. Chwyt ten nie był jednak najskuteczniejszy - wypisany białymi literami tekst krótkiego, nie niosącego żadnego komunikatu hasła, podobnie jak nazwisko jego autorki wtapia się w tło. Zdjęcie nie wywołuje żadnych skojarzeń - mogłoby być równie dobrze portretem przeciętnej Francuzki. Projekt plakatu Sarkozy'ego, na którym kandydat został ujęty na tle sielskiego (wyraźnie europejskiego) pejzażu z rozległym horyzontem, nawiązuje podobnie jak hasło „Razem wszystko staje się możliwe” - do związków z krajem, do otwarcia na nowe szanse, wreszcie - przez kolorystykę, odmienną od kontrastowych barw u Royal - do harmonii i spokoju. Jednocześnie postać przedstawiona na fotografii nie zdaje się spoufalać $\mathrm{z}$ widzem. Jej poza i wyraz twarzy kreują wrażenie autorytetu i dystansu, które cechują prezydenta, niebędącego wszak przeciętnym obywatelem ${ }^{17}$.

Kulminacyjnym momentem każdej kampanii wyborczej w krajach demokracji zachodniej jest debata między dwoma najwyżej plasującymi się kandydatami. We Francji miała ona miejsce 3 maja. Głosy francuskich dziennikarzy oraz politologów były zgodne - choć poziom dyskusji, wysuwania argumentów i odpierania ciosów przeciwnika był raczej wyrównany, na niekorzyść Royal zadziałała sześciopunktowa strata w sondażach w stosunku do rywala. Chcąc „zaistnieć” w mediach i wyraźnie zaznaczyć swoją stanowczość, zdecydowanie i determinację, Royal gorzej niż Nicolas Sarkozy opanowywała emocje, również te pozytywne. Z jednej strony jej ataki na kontrkandydata uznano za nieco zbyt agresywne, a z drugiej - uśmiech, dynamika, żywa gestykulacja zostały odebrane jako nielicujące $\mathrm{z}$ powagą urzędu, który, według znacznej większości Francuzów, powinna piastować osoba stateczna ${ }^{18}$. Atut $\mathrm{w}$ debacie stanowiła płeć Royal - Sarkozy, chcąc

C. Filâtre, Les affiches de la campagne, „Le Monde”, nr 74, 2007, s. 16.

18 Por. K. Niklewicz, Francuski ekspert o debacie telewizyjnej między kandydatami na prezydenta Francji, „Gazeta Wyborcza”, nr 126, 2007, s. 3. 
uniknąć oskarżeń o grubiaństwo wobec kobiety, nie zaprezentował pełni swoich możliwości oratorskich, co, w niezbyt fortunny, jak się okazało, sposób, wykorzystała jego rywalka. Próbowała ona zarazić widzów swoim entuzjazmem, a przez przekonanie, jakie wkładała w prezentację swoich postulatów, udowodnić ich prawdziwość i skuteczność. Sarkozy i jego doradcy skutecznie przewidzieli oczekiwania wyborców - kandydat jawił się jako osoba stanowcza, odnosząca sukcesy dzięki celowym, przemyślanym działaniom, a nie gwałtownym zrywom. Wystąpienie Royal zostało uznane za przekonujące niezdecydowanych, jednakże nieprowadzące do odrobienia straty. Zważywszy natomiast na fakt, iż głosy Francuzów od początku były podzielone niemal wyłącznie między dwoje powyższych kandydatów, to właśnie osiągnięcie drugiego celu - wyrównania różnicy w sondażach - powinno stanowić priorytet kandydatki. Pozycja Sarkozy'ego, przez całą kampanię zmagającego się z etykietą polityka skutecznego, lecz potencjalnie niebezpiecznego w swych radykalnych zamiarach, zdecydowanie się umocniła, gdyż udało mu się przekonać widzów, iż kondycja kraju wymaga „rządów silnej ręki”. Georges Mink, francuski politolog, podsumowując debatę, uznał wyższość strony merytorycznej nad zabiegami marketingowymi. Stwierdził on, że wygrał Sarkozy, ponieważ był po prostu lepiej przygotowany, a co za tym idzie - bardziej pewny siebie ${ }^{19}$.

\section{„Ludzie mówią", czyli opinie wyborców}

Jak przystało na jedno z najistotniejszych wydarzeń politycznych, wybory prezydenckie zebrały niezliczoną ilość komentarzy - tym większą, że kampanią żywo interesował się niemal ogół społeczeństwa, czego dowodzi imponująca frekwencja, przekraczająca $84 \%$ w drugiej turze. Kandydatów chwalono i atakowano, brano pod uwagę merytoryczną wartość ich oferty, ale także czynniki, których w żadnej mierze merytorycznymi nazwać nie można. Te same cechy i fakty, które dla jednych stanowiły niepodważalne zalety, inni postrzegali jako nieprzezwyciężalne wady.

Jakie więc kwestie oraz cechy kandydatów, znajdujące się poza sferą rzeczowych argumentów, stanowily przedmiot dyskusji oraz komentarzy? W przypadku Ségolène Royal najistotniejszym punktem stał się wspomniany już aspekt płci - obecność kobiety w kampanii wyborczej zdecydowanie ją łagodziła. Trudno przewidzieć czy wyrafinowany styl i wyważone argumenty kandydata prawicy zostałyby zachowane, gdyby jego najważniejszym prze-

Dostępne: http://www.money.pl/archiwum/wiadomosci_agencyjne/iar/artykul/salon; trojki;politolog;georges;mink;o;nicolasie;sarkozym;i;segolene;royal,231,0,239591.html [20.01.2008] 
ciwnikiem byłby np. François Bayrou. Na korzyść Royal w pewnym stopniu przemawiała także jej sytuacja rodzinna - mimo że nie angażował się w kampanię, postać partnera kandydatki, lidera Partii Socjalistycznej François Hollande'a przyczyniała jej wyborców, głosujących niejako za pewnymi ideałami uosabianymi przez partię, podlegającymi w tym przypadku „zdublowaniu". Sytuacja rodzinna Royal oraz sposób, w jaki łączy ona wychowywanie dzieci z karierą polityczną, tworzyły wokół niej atmosferę opiekuńczości oraz gospodarności. Wśród odpowiedzi na pytanie o źródła poparcia padały również argumenty o urodzie kandydatki oraz wrażeniu ciepła i życzliwości, jakie sprawia.

Fakt, iż pretendentką do stanowiska prezydenta była kobieta oraz jej sytuacja rodzinna $-\mathrm{z}$ jednej strony aprobowane, $\mathrm{z}$ drugiej spotkały się również z nieprzychylnymi komentarzami. Poproszona o opinię na temat Royal pisarka Claire Gallois stwierdziła: „Pierwszą i największą jej zaletą jest kobiecość, a drugiej... nie znalazłam" ${ }^{20}$. Laurent Fabius, usłyszawszy o zamiarach kandydowania Royal, skwitował je pytaniem „kto zajmie się dziećmi” oraz dodał, że „wybory to nie konkurs piękności” ${ }^{21}$. Wyborcy podkreślali niezadowolenie $\mathrm{z}$ faktu, iż socjalistka od ćwierćwiecza znajduje się w niezalegalizowanym związku. Oceny jej życia prywatnego były niższe nawet od opinii o François Mitterandzie, który oprócz żony posiadał niemal oficjalną kochankę, a publiczne pojawienie się ich - już dorosłej - córki zostało taktownie przemilczane. Co gorsza, fakt, że Royal jest matką dość licznego potomstwa - dla niektórych zamiast podtrzymywania rodzinnego szczęścia oznaczał upadek obyczajów oraz skrajną nieodpowiedzialność. Paradoksalnie kryzys małżeński Sarkozy'ego i zdrady, których dopuszczała się Cécilia, jego żona, z marketingowego punktu widzenia zaszkodził mu mniej niż brak ślubu jego kontrkandydatce. Opinia publiczna opowiadała się za Sarkozym to on został opuszczony, lecz nie wykorzystał tego faktu, by zagrać na emocjach wyborców. Sympatii przysporzyło mu usunięcie redaktora naczelnego brukowca, który na okładce opublikował zdjęcia byłej małżonki Sarkozy'ego z nowym partnerem. Rodzina i wszystko, co z nią związane, okazała się więc kwestią dużo istotniejszą w przypadku Royal, pozostając w kampanii jej konkurenta sprawą mniejszej wagi. $\mathrm{W}$ obliczu współczesnych tendencji w polityce światowej, rosnącego zaangażowania kobiet w życie polityczne, kandydatury Hillary Clinton na stanowisko prezydenta USA, należy zaznaczyć, iż „obraz kobiety-kandydata może stanowić prawdziwe wyzwanie dla specjalistów zajmujących się marketingiem politycznym". Mimo że szanse kobiet na

F. Bazin, Comment battre Sarkozy, „Nouvel Observateur”, nr 4, 2007, s. 26.

Dostępne: http://www.laurent-fabius.net/article8.html [20.01.2008]. 
sukces wyborczy teoretycznie uznawane są za niewielkie, praktyka dostarcza przykładów obalających to stwierdzenie, szczególnie, kiedy kobiety okazują się bardziej kompetentne oraz moralne niż ich rywale ${ }^{22}$.

W odniesieniu do kandydata prawicy znacznie istotniejsze niż płeć, wygląd oraz posiadanie niewiernej żony okazały się - rzeczywiste lub domniemane - cechy jego charakteru. Trudno podzielić je na atuty oraz wady, ponieważ to, co według stanowiska zwolenników Royal stanowiło zagrożenie dla ładu i wartości republikańskich, wedle popleczników Sarkozy'ego miało owe wartości ocalić. Bez wątpienia najistotniejszą, wyraźnie podkreślaną także za granicą, cechą kandydata, była zdolność wyraźnego formułowania poglądów, nawet kosztem polaryzacji społeczeństwa i konieczności stawiania czoła wrogom ${ }^{23}$. Thibault Camus $\mathrm{w}$ „Washington Post” podkreślał, iż Sarkozy uosabia nowy, zrównoważony styl kierowania ${ }^{24}$. Zauważano także podobieństwo owego stylu do najlepszych (zdaniem autora artykułu) metod sprzed kilkudziesięciu lat, nazywając polityka UMP „genetycznie zmodyfikowanym gaullistą, wydobywającym walory Francji”25. Stanowczość, nieustępliwość oraz pewność, z jaką Sarkozy zapowiadał zaprowadzenie ładu w kraju budziły jednak także niepokój, nawet wśród osób skłonnych oddać głos na kandydata prawicy. Kwintesencją wątpliwości, jakie żywili Francuzi przed wyborami, było często powtarzane pytanie: „na ile Sarkozy jest niebezpieczny, a Royal - kompetentna?”. Tak też według jednych Sarkozy „ucieleśniał dynamikę (...), jego żywiołem było działanie oraz rozwiązywanie problemów"26, natomiast inni widzieli w tym źródło zagrożeń - Adam Sage twierdził w „Timesie”, iż "jego polityka może doprowadzić do wybuchu przemocy" ${ }^{27}$. Kandydat ten stworzył wizerunek człowieka reprezentującego określony światopogląd, ale i konsekwentnego, statecznego, bez wątpienia posiadającego jasno sprecyzowane plany. Nie sposób zarzucić mu braku wyrazistości, czego nie można powiedzieć o Royal - cechy jej charakteru w kampanii właściwie nie istniały. Mówiono, że jest chwiejna, że brak jej charyzmy oraz jednolitego, skierowanego do konkretnej grupy odbiorców wizerunku. Cecile Amar wspomina wprawdzie o autorytarnych zakusach i ogromnych ambicjach kandydatki ${ }^{28}$, uznaje to jednak za atut $\mathrm{w}$ dążeniu do prezydentury i przyznaje, iż autorytaryzm ten dotyczył raczej jej najbliższe-

22 W. Cwalina, A. Falkowski, Marketing polityczny. Perspektywa psychologiczna, Gdańsk 2005, s. 238.

23 H. J. Kaffsack, Der dritte Mann, „Der Tagesspiegel”, nr 28, 2007, s. 2.

24 T. Camus, Strikers Defying Nicolas Sarkozy, „Washington Post”, nr 8, 2007, s. 6.

F. Giavazzi, Francia, metà degli elettori non sa chi votare, „Corriere della Sera”, nr 30, 2007, s. 4.

A. Veiel, Viel Applaus Für Sarkozy, „Berliner Zeitung“, nr 25, 2007, s. 6.

A. Sage, Sarkozy's perfect week, ,Times”, nr 27, 2007, s. 11.

C. Amar, D. Hassoux, Ségolène et François - biographie d'un couple, Paryż 2005, s. 78. 
go otoczenia. Sarkozy narzucał, był pewny siebie i politycznie niepoprawny, natomiast Royal ograniczała się do propozycji i postulatów. Chcąc wprowadzić do polityki nową jakość, usiłowała trzymać się zasad savoir-vivre’u. Zachowanie to, z etycznego i merytorycznego punktu widzenia pozytywne, nie miało wiele wspólnego z marketingiem politycznym. Dlatego też Sarkozy był główną postacią tej kampanii. To o nim powstawały tysiące stron internetowych - nawet jeśli go ośmieszały, tym samym powodowały dyfuzję jego poglądów i wypowiedzi, tak jak stało się w przypadku witryny internetowej sarkopitheque.wordpress.com, stanowiącej ogromne archiwum materiałów będących pastiszami, parafrazami oraz zmontowanymi nagraniami dotyczącymi kandydata. Niewielka popularność tego typu działań podejmowanych w odniesieniu do socjalistki świadczy o tym, iż nie była ona w stanie wzbudzić emocji, niezbędnych w grze wyborczej.

\section{Kampania w słupkach, czyli moc sondaży}

Oprócz zwyczajowych już sondaży przeprowadzanych w klasyczny sposób, na określonej próbie reprezentatywnej, z zachowaniem wszelkich wymogów metodologicznych, novum w kampanii prezydenckiej 2007 były badania prowadzone według niezwykle oryginalnych kryteriów. Miały one miejsce np. w supermarketach, o różnych porach dnia, aby dotrzeć do niepracujących kobiet robiących zakupy przed południem $\mathrm{w}$ dni robocze, przedstawicieli klasy średniej zaopatrujących się w produkty przy okazji powrotu z pracy oraz rozbawionej młodzieży, kupującej alkohol tuż przed zapadnięciem sobotniej nocy. Co istotne, w sondażach „supermarketowych” zwyciężał Sarkozy, lecz dzięki minimalnej, wahającej się od setnych procenta do dwóch procent, przewadze. Przeprowadzono także sondaż ukierunkowany na markę posiadanego samochodu. Okazało się, iż „lewicową” marką jest tradycyjny Renault (co interesujące, marka ta przez wiele lat po wojnie stanowiła własność państwową) - jego właściciele deklarowali oddanie głosu na Ségolène Royal. „W prawo” kierowali się posiadacze Peugeotów i Citroenów ${ }^{29}$.

Nieco bardziej reprezentatywne badania wskazywały jednak, iż Royal oraz Sarkozy rozpoczynali kampanię z jednakowymi szansami. Poparcie dla kandydatki spadało z miesiąca na miesiąc co prawda o niewielkie wartości, lecz nieprzerwanie. Sondaż telefoniczny dla dziennika „Le Parisien” przeprowadzony bezpośrednio po debacie wykazał, że Royal przekonała do siebie $37 \%$ wyborców, podczas gdy na Sarkozy'ego było gotowych zagłosować

29 Dostępne: http://zfrancjiofrancji.salon24.pl/13125,index.html [20.12.2007]. 
$47 \%^{30}$. 6 maja, w II turze wyborów, Royal straciła w stosunku do rywala $6 \%$, co obiektywnie stanowi co prawda niewielką różnicę, lecz biorąc pod uwagę fakt startu z podobnego punktu wyjścia oraz deklarowaną wstępnie przychylność wyborców, można ten wynik uznać za porażkę. Opinię tę pogłębia fakt, iż to nie Sarkozy zwiększał poparcie swoimi działaniami, lecz, prowadząc niezbyt aktywną kampanię, zyskiwał głosy niezdecydowanych, które, najpierw zyskawszy, przez liczne potknięcia straciła jego kontrkandydatka.

Analizy wyników wyborów pod względem profilu wyborcy wykazały, iż zdobyła ona zaufanie większej liczby mężczyzn niż kobiet (co interpretuje się przewagą tej płci wśród głosujących muzułmanów), klasy średniej, zatrudnionej w sektorze usługowym oraz robotników. Linia podziału między zwolennikami socjalistki a Sarkozy'ego, na którego głosowali m.in. handlowcy, prawnicy, lekarze, bardzo wyraźnie potwierdza skuteczność obranej strategii przedwyborczej. Podobną sytuację obserwuje się w przypadku struktury wiekowej - osoby bardzo młode, obawiające się o swoją edukację i rozwój, a także wyborcy w wieku przedemerytalnym, zaniepokojeni sytuacją na rynku pracy oraz reformami systemu opieki społecznej, zdecydowali się oddać głos na Royal. Osoby w pełni aktywne zawodowo oraz tradycjonaliści w podeszłym wieku zaufali Sarkozy'emu ${ }^{31}$.

\section{Zwycięstwo programu czy wizerunku?}

Skoro kandydaci rozpoczynali kampanię z porównywalnym poparciem, a w czasie jej trwania żadne z nich nie osiągnęło niemożliwej do wyrównania przewagi, dlaczego zwycięzcą został właśnie Sarkozy? Oferta Royal, mimo bazowania na nieco archaicznym programie socjalistów, nie była nie do przyjęcia. Poruszała problemy, których nierozwiązanie w najbliższym czasie grozi dalszym pogarszaniem się złej sytuacji gospodarczej, a co za tym idzie, nasileniem konfliktów społecznych i rozprzestrzenieniem ich także na te grupy, które dotychczas nie miały powodu protestować. Kandydatka ze swoim przyjacielskim, otwartym wizerunkiem miałaby szanse zwyciężyć, gdyby jej przeciwnikiem była osoba mniej wyrazista niż Sarkozy. Wówczas to, co w konfrontacji z rywalem o tak silnej osobowości, podkreślanej różnorodnymi technikami marketingowymi, zadziałało na niekorzyść socjalistki, mogłoby okazać się atutem. Nie wytykano by jej płci, nie szukano by miałkości w jej programie, być może nie zwrócono by także uwagi na nie najkorzystniejszą stronę internetową czy spoty telewizyjne. Kandydatura

30 Badania IPSOS France, dostępne: http://geoconfluences.ens-lsh.fr/doc/breves/2007/ 1.htm [2.05.2007].

31 Badania IPSOS France, dostępne: http://www.eurazeo.fr/uk/04_communication/commu niques-eurazeo.php [14.05.2007]. 
Royal zostałaby zapewne zaakceptowana jako oferta osoby posiadającej własne poglądy, łączącej karierę polityczną z życiem rodzinnym. Wybory wygrał Sarkozy i była to logiczna, naturalna konsekwencja dobrze, skutecznie prowadzonej kampanii. Wykorzystano i uwydatniono wszystkie atuty, których nie miał więcej niż Royal. Zachowania kandydata, jego wypowiedzi, gestykulację, mimikę dopracowano w najmniejszych szczegółach, by uniknąć jakiejkolwiek sytuacji, którą wytknąłby sztab przeciwniczki, skrupulatnie wyszukując przy tym jej potknięcia. Kontrowersyjne hasła przedstawiono jako zapowiedź konstruktywnych zmian, niemożliwych do przeprowadzenia stopniowo i bezboleśnie.

W dobie, w której kandydat na stanowisko głowy państwa zostaje przez specjalistów od reklamy sprowadzony do rangi kartonu z mlekiem, należy zadbać nie tylko o rzetelną informację, lecz także o atrakcyjne opakowanie oraz o to, by konkurencja nie wpadła na lepsze pomysły. Sztab Sarkozy'ego wywiązał się z tego zadania wzorowo. Publicysta „Rzeczpospolitej” Grzegorz Dobiecki, komentując wynik wyborów, stwierdził: „Wybory zamieniły się w referendum: za lub przeciw Sarko. Wychodząc zwycięsko z takiej próby, zyskuje się szczególną legitymację do sprawowania władzy i bardzo mocną pozycję osobistą na jej szczycie"32.

M A R T A D O R E N D A

32 G. Dobiecki, Prezydent nie wszystkich Francuzów, „Rzeczpospolita”, nr 98, 2007, s. 2. 


\section{Non-meritorical factors in presidential campaign in France, 2007}

The article, concerning a campaign before last presidential election in France, underlines the influence of political marketing on citizens' choices and spin doctors' work's superiority over genuine political offer.

Despite official registration of 12 candidates, only two amongst them were seriously taken into consideration. Moreover, public opinion research held before the elections indicated an equal level of support both for Nicolas Sarkozy - a conservative candidate - and Ségolène Royal - a socialist one, which meant that only a professionally performed campaign could have decided who the winner was.

The author analyses the techniques and strategies used by both candidates and their counselors. The segmentation of political market is strongly emphasised - while Sarkozy's campaign aimed at older, stable voters, constituting French upper and upper-middle class, strongly cultivating republican tradition and rather unfavourable towards immigrants, Royal addressed her statements to these marginalised groups. Such a division directly influenced the means of communication used in the campaign - Royal, trying to create an image of a friendly, open-hearted and modern person, chose open meetings and the Internet as channels of expression. Using popular services such as youtube.com or myspace.com, she managed to mobilise young voters, spontaneously promoting Ségolène's ideas in their environment. Contrary to that, her rival admitted the importance of online action much later, nevertheless his website, as well as other aspects of the campaign, was incomparably more professional. Both Sarkozy's programme and the actions of purely promotional meaning, despite the accusations of nationalism or xenophobia, were internally logical and coherent. What is more, a few cases of Royal's ridiculous answers to basic questions contrasted with Sarkozy's orientation in politics and economy.

Opening the competition with equal chances, one candidate made public opinion concentrate on her hairstyle and family life, and the other gained an image of responsible politician, ready to lead the country and fight a crisis. As a comparison of both candidates' abilities does not show significant disproportion, such a success can mainly be concerned as a result of an efficiently led campaign. 